\title{
Southernmost record of the Giant Manta Ray Mobula birostris (Walbaum, 1792) in the Eastern Pacific
}

\author{
Bernabé Moreno ${ }^{1,2}$ (D) and Adriana Gonzalez-Pestana ${ }^{1,3,4^{*}}$
}

\begin{abstract}
Background: Manta rays (Mobulidae), Mobula birostris and Mobula alfredi, are widely distributed in tropical and temperate waters. Still, little is known about their movements and their ecological interactions (e.g. behavior and diet). In Peru, M. birostris has only been reported along the northern shore within the Tropical East Pacific Marine Province. No official reports exist from central or south Peru within the Warm Temperate Southeastern Pacific Marine Province.

Methods: On December 22nd 2015, a rare sighting of a $\sim 4 \mathrm{~m}$ disc width mobulid ray was recorded as video footage near the Palomino Islets, Lima, Peru.

Results: In situ observations and subsequent analysis of the footage confirmed that this single mobulid was a $M$. birostris with a melanistic color morph.

Conclusions: This sighting could be explained by the warm El Niño, primary (chl-a), and secondary (zooplankton) productivity events during that same period. This represents the southernmost record of M. birostris in the southeastern Pacific $\left(12^{\circ} \mathrm{S}\right)$ and the first report of this species in the Warm Temperate Southeastern Pacific Marine Province and in the Humboldt Current Large Marine Ecosystem.
\end{abstract}

Keywords: Sighting, El Niño, Peru, Southeastern Pacific, Marine province

\section{Background}

Until recently, manta rays belonged to the genus Manta which formally comprised two re-described species: the Giant Manta Ray (M. birostris) and the Coastal Manta Ray (M. alfredi). In addition to these, the putative species $M$. cf. birostris (suggested as M. giorna by Marshall et al., 2009) was consistent with the recent publication of the potential species of Yucatán manta ray (Hinojosa-Alvarez et al., 2016). White et al. (2017) have updated the taxonomic arrangement of the Mobulidae family nesting the members of the genus Manta within the Mobula species. Manta rays (referring now to $M$. birostris and $M$. alfredi) are pelagic planktivores, the largest batoid fishes in the world (Marshall et al., 2011) and reported to occur circumglobally in tropical and temperate waters (Couturier

\footnotetext{
* Correspondence: adri_gonpe@hotmail.com

${ }^{1}$ Carrera de Biología Marina, Universidad Científica del Sur, Panamericana Sur km 19, 42 Lima, Peru

${ }^{3}$ ProDelphinus, Jose Galvez 780, 18 Lima, Peru

Full list of author information is available at the end of the article
}

et al., 2012). M. birostris is considered the more widely distributed member of the genus as it is broadly spread in the Pacific, Atlantic and Indian oceans (Marshall et al., 2009) while $M$. alfredi is absent from the Eastern Pacific (Couturier et al., 2012; Lawson et al., 2017). Several biological traits (i.e. slow growth, late sexual maturation and low fecundity) of these species make them prone to overexploitation (Dulvy et al., 2008; Deakos et al., 2011). In addition, two of the most direct threats are by-catch and the high demand for its gill rakers by the Asian market (White et al., 2006). Therefore, the International Union of the Conservation of Nature (IUCN) has assessed the conservation status of both manta ray species as vulnerable to extinction (Marshall et al., 2011, IUCN Red List). Moreover, The Convention on International Trade in Endangered Species of Wild Fauna and Flora (CITES) included $M$. birostris species in appendix II; while the Commission of Migratory Species (CMS) included M. birostris in appendices I and II. 
Five species of the Mobulidae family have been officially reported in northern Peru (up to $6^{\circ} \mathrm{S}$ ): $M$. birostris, $M$. mobular, M. munkiana, M. tarapacana, and M. thurstoni (Chirichigno \& Cornejo, 2001). However, M. birostris is commonly allocated in distribution maps that extend its occurrence to southern Peruvian limits (e.g. Marshall et al., 2011; Lawson et al., 2017). Peruvian waters present two marine provinces (MP) (Spalding et al., 2007; http:// www.marineregions.org/sources.php): 1) the Tropical East Pacific (TEP-MP), characterized by the Equatorial Current; and 2) the Warm Temperate Southeastern Pacific (WTSP$\mathrm{MP})$, characterized by the Humboldt Current and the associated upwelling of cold nutrient-rich waters. From these two marine provinces, $M$. birostris have only been reported in the TEP-MP; moreover, this species has not been reported in the Humboldt Current Large Marine Ecosystem (HC-LME). Therefore, the aim of this study is to report and establish the southernmost record of $M$. birostris in the southeastern Pacific and its first report in the WTSP-MP and HC-LME.

\section{Methods}

On December 22nd 2015, one of the authors (BM) performed a diving excursion to the Palomino Islets which are located on Peruvian central coast, $8.9 \mathrm{~km}$ away from La Punta, Callao (Fig. 1).The Palomino Islets are located $2.6 \mathrm{~km}$ from Cavinzas Island and together they comprise a Natural Protected Area covering 5146 ha (Sernanp, 2009). BM was carrying an action-cam GoPro Hero2 model, a compass and a Cressi Leonardo dive computer, which measured depth and water temperature. For the approximate identification of the mobulid, individual visible diagnostic characteristics (excluding dentition) described by Marshall et al. (2009) and Hinojosa-Alvarez et al. (2016) were used (Table 1). The distinctive features included: terminal mouth, large and unfurl cephalic fins, ventral spot pattern clustered around lower abdominal region, trailing underside edge of pectoral fins usually shaded black, gill covers often with black shading/flaring, and white shoulder markings form two mirror image right angled triangles which creates the letter $\mathrm{T}$ in black across the top of the head. Both $M$. birostris and $M$. alfredi show a melanistic form, described as entirely black on the dorsal surface and predominantly black on the ventral surface (Marshall et al., 2009).

\section{Results}

During the dive an unusual encounter with a large mobulid individual was registered on video nearby the Palomino Islets (Fig. 1), 12 $07^{\prime} 37.01^{\prime \prime}$ S; 77¹3'50.76" $\mathrm{W}$. The sighting was registered at a depth of $16 \mathrm{~m}$, where temperature was $18{ }^{\circ} \mathrm{C}\left(\mathrm{SST}: 19^{\circ} \mathrm{C}\right)$, water was turbid ( $\sim 6 \mathrm{~m}$ visibility), greenish, and the bottom sediment at $18 \mathrm{~m}$ was composed of sand and deposits of broken shells.
Mouth position was the first morphological observation to discriminate between all possible Mobula species. The sighted mobulid had a terminal mouth which is a key trait to restrict it to the larger Mobula species (Table 1). Also, it had $\sim 4 \mathrm{~m}$ disc width (DW) and long unfurled cephalic fins. Based on the dorsal coloration it was a melanistic morph of manta ray, with a centered white ventral pattern (Fig. 2).

Eleven sucker fish (Remora sp.) were counted below the ventral zone, and one above the dorsal zone next to the dorsal fin. Although remoras were located in the gill area, gill slits covered with black shading could be observed. Based on the diagnostic traits (Table 1), $M$. alfredi was less likely as the expected body and mouth coloration differed from the observed individual and there was no embedded caudal spine. Both Yucatán manta ray and $M$. birostris presented the same diagnostic traits as the sighted individual.

The cephalic fins were closed while swimming across the water column $2 \mathrm{~m}$ above the seafloor, suggesting a non-feeding behavior (Ari \& Correia, 2008). The widening of the branchial gills could not be assessed because of the presence of sucker-fishes below them, which impeded the determination of a definite feeding behavior. Additional observations include dense mats of red squat lobsters (Pleuroncodes monodon) on the surface and several dozen siphonophores in the water column.

Video footage of the sighting is available at https:// vimeo.com/150842390 (Peruvian Dark Angel).

\section{Discussion}

Due to similarities in their body size and external appearance, mobulids are often confused in the field (Couturier et al., 2012). Location of the mouth is a key diagnostic characteristic between manta rays and devilrays, being terminal and subterminal respectively. Based on the terminal mouth, body size and coloration patterns, the sighted mobulid was undoubtedly a manta ray. The largest representatives of the Mobula genus (White et al., 2017), commonly known as manta rays, have two officially defined species: M. birostris and M. alfredi, which have many morphological characters in common and close similarities at the molecular level (Kashiwagi et al., 2012). Their evolutionary divergence is thought to be relatively recent (1 Ma), in contrast to e.g. M. rochebrunei and M. munkiana (2.59 Ma) (Poortvliet et al., 2015).

The IUCN Red List states that historical reports of both $M$. birostris and $M$. alfredi are often mixed since the re-description and separation of the species was published in 2009; therefore, reports and distribution ranges should acknowledge this. Also, relying only on color morphologies could be a possible source of error resulting in misidentifications (Visser et al., 2004). One hybrid (M. birostris $\mathrm{x} M$. alfredi) has been reported through 


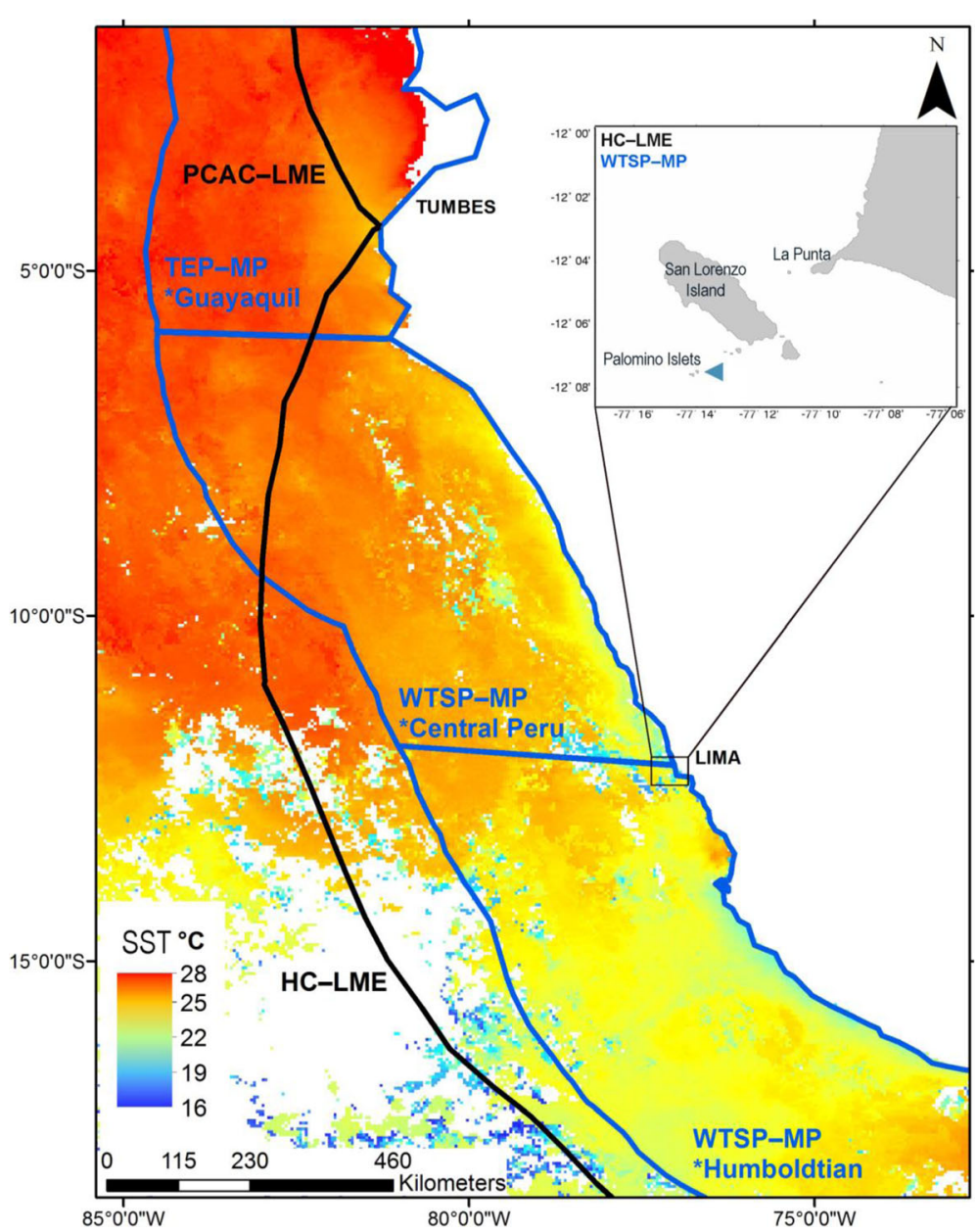

Fig. 1 Sea Surface Temperature (SST) composite and location of the southernmost sighting of Mobula birostris off Peruvian Central Coast. Geographic demarcation showing the Pacific Central-American Coastal Large Marine Ecosystem (PCAC-LME) and the Humboldt Current LME (HC-LME) on black lines; and the Tropical East Pacific Marine Province (TEP-MP) and the Warm Temperate Southeastern Pacific MP (WTSP-MP) on blue lines. Exact location of the sighting is marked with $\mathbf{4}$ on the extended figure to the right. The 8-day composite (19-26 December 2015) was obtained from the Aqua MODIS Sea Surface Temperature (SST) (11 $\mu$ daytime) satellite (http://oceancolor.gsfc.nasa.gov/) and the regions polygons from the Marine Regions http://www.marineregions.org/sources.php

Table 1 Diagnosis traits comparison chart (modified from Hinojosa et al., 2016) between the sighted individual, M. birostris, M. alfredi, and the putative additional species off Yucatán (Hinojosa et al., 2016). Present: 1; absent: 0

\begin{tabular}{|c|c|c|c|c|}
\hline Visible diagnosis traits & Sighted Mobula sp & M. birostris & M. alfredi & Yucatán manta ray \\
\hline Mouth color (white:0; black:1) & 1 & 1 & 0 & $0 ; 1$ \\
\hline Black dorsal surface & 1 & 1 & 1 & $1 ;$ brown \\
\hline $\begin{array}{l}\text { Triangular-shaped shoulder patches } \\
\text { in supra-branchial region (Unless } \\
\text { melanistic form) }\end{array}$ & melanistic & 1; melanistic & 0 & 1; melanistic \\
\hline $\begin{array}{l}\text { Dark spots between the five gill } \\
\text { slits or pectoral fins }\end{array}$ & 0 & 0 & 1 & 0 \\
\hline $\begin{array}{l}\text { Calcified mass with an embedded } \\
\text { spine on the dorsum of tail immediately } \\
\text { posterior to dorsal fin }\end{array}$ & 1 & 1 & 0 & 1 \\
\hline
\end{tabular}




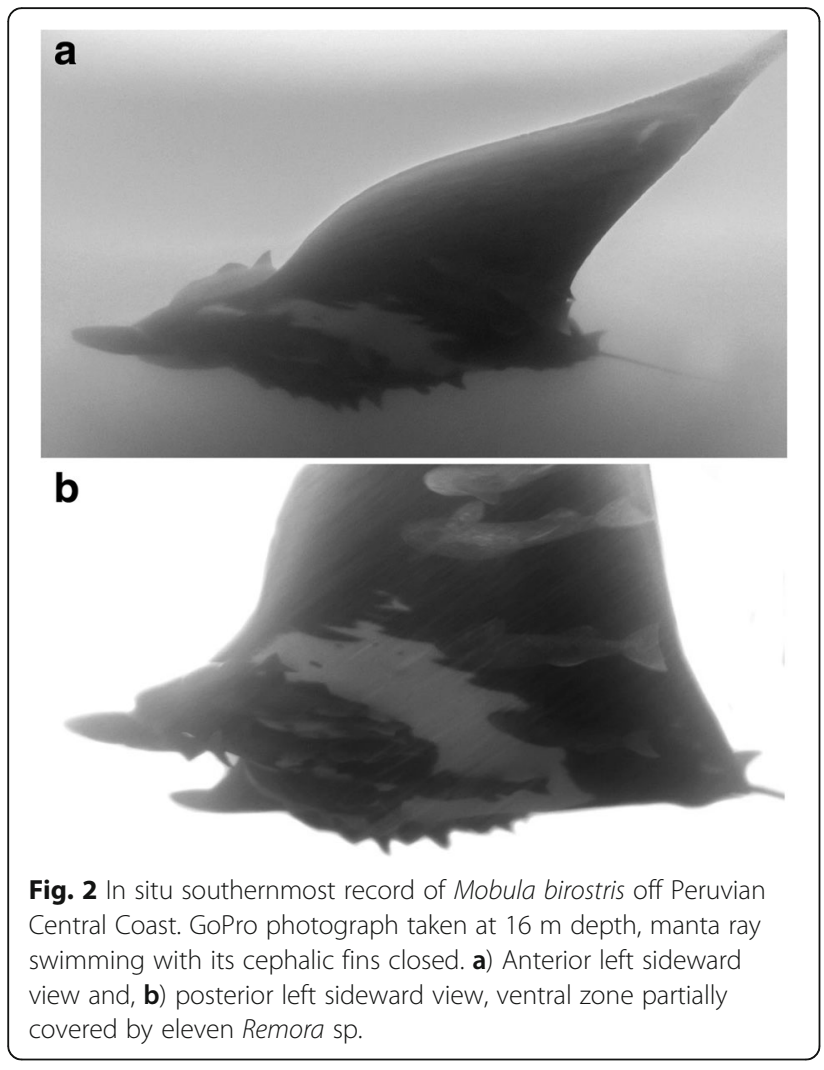

genetic analysis by Walter et al. (2014) even though it was initially identified as a $M$. alfredi in the field. Similarly, in Kashiwagi et al. (2012) several specimens that were visually identified as $M$. alfredi ended up separating out genetically as $M$. birostris. These facts highlight the need for molecular tools to confirm and validate whether an individual is one species or another -or a hybrid- especially in individuals occurring in sympatry (Marshall et al., 2009; Kashiwagi et al., 2011). Recently, by using molecular tools, a third potential species of manta has been suggested from a resident population in the Yucatán Peninsula. This latter has been hypothesized to have genetically diverged from $M$. birostris between 0.028-0.056 Ma (Hinojosa-Alvarez et al., 2016) and it poses a challenge as it shows morphological similarities to both $M$. alfredi and M. birostris (Table 1).

Non-invasive techniques were performed to identify the observed individual, and as such, statements at the species level cannot be conclusive. Nevertheless, potential paths of arrival should also be considered. Rare and seasonal sightings (Duffy \& Abbott, 2003; Luiz et al., 2009) together with broad-scale movements $>1000 \mathrm{~km}$ (Rubin et al., 2008) suggest a notable seasonal migration for $M$. birostris. However, this hypothesis has recently been challenged by Stewart et al. (2016) using three complementary techniques to conclude that the species appears to exhibit restricted movements and fine-scale population structure in three different locations (i.e. Revillagigedo Islands and Baja California in Mexico, and Raja Ampat in Indonesia). Regardless, $M$. birostris is thought to be a more oceanic and migratory species than $M$. alfredi as the latter has usually been re-sighted in aggregation sites (Marshall et al., 2011; Braun et al., 2015). Thus, $M$. alfredi is considered to have a smaller habitat range and to be more resident in tropical waters (Marshall et al., 2009) with seasonal migrations up to $500 \mathrm{~km}$ (Couturier et al., 2012). Moreover, the Eastern Pacific Barrier (Ekman, 1953) could pose a spatial (ca $5000 \mathrm{~km}$ ) and environmental (i.e. low-productivity) barrier to the colonization of $M$. alfredi from southeastPolynesian populations towards the Eastern Pacific region (Cowman \& Bellwood, 2013). Additional to this, the current report is from the southeastern Pacific, strongly suggesting an allopatric separation from Yucatán manta rays as these are thought to be resident -and potentially endemic- in the Caribbean (Hinojosa-Alvarez et al., 2016) and some parts of the Western Atlantic (Marshall et al., 2009). The sighted individual is likely to belong to one of the world's largest populations of $M$. birostris in Ecuador that usually migrates south towards tropical Peruvian waters (Andrea Marshall pers. comm.).

According to Chirichigno \& Cornejo (2001), Marshall et al. (2009), Avila et al. (2014) and anecdotal sightings (Daniel Cáceres pers. comm.), Piura (northern Peru) is the southernmost distribution of $M$. birostris in Peru which is located in the TEP-MP. Only three Mobula species have been reported in Chile (none of these was $M$. birostris), but these are either rarely collected specimens or dubious record of the species (Bustamante et al., 2014). Central and southern Peru share the same marine province as Chile, the WTSP-MP, and the same large marine ecosystem, the HC-LME. Yet, M. birostris is commonly allocated in distribution maps that extend its occurrence to southern Peruvian limits (Marshall et al., 2011; Couturier et al., 2012) and northern Chile (Lawson et al., 2017). The sources of these distribution ranges remains unclear as they are not based on official reports. Therefore this sighting represents the southernmost record of $M$. birostris in the eastern Pacific and the first report of this species in the WTSP-MP and HC-LME.

The distribution of manta rays in tropical and subtropical waters suggest an apparent preference for water temperature of $20-26{ }^{\circ} \mathrm{C}$ (Dewar et al., 2008; Marshall et al., 2011). In northern Peru the regular SST on summer is between 20 and $23{ }^{\circ} \mathrm{C}$; yet during this warm El Niño event the SST rose up to $28{ }^{\circ} \mathrm{C}$. In central Peru, the month of December, 2015 presented positive anomalies according to two El Niño indices: +4.5 for the Coastal El Niño Index (acronym in Spanish, ICEN) which is a coastal index representative at a local scale (Takahashi et al., 2014), and +3.7 for the Peruvian Oscillation Index 
(POI) which is a large scale index representative of the central Pacific Ocean (Purca et al., 2000), and at the time of the sighting $19{ }^{\circ} \mathrm{C}$ SST was registered in situ, representing a $+3{ }^{\circ} \mathrm{C}$ SST anomaly (Enfen, 2015). Hence, this sighting could be explained as a consequence of a warm El Niño event. Warming in the Peruvian Central Coast waters could have induced this individual to migrate south as northern Peru presented SST above its range preference, which is considered a biological impact of El Niño 2015-16 (Enfen, 2015). The occasional occurrence of certain ichthyofauna species at higher latitudes of the southeastern Pacific Ocean are usually related to warm El Niño events (Hooker, 1998; Espino, 1999). For example, the occurrence of M. tarapacana and M. mobular in northern Chile has been associated with El Niño (Sielfeld et al., 2010; Bustamante et al., 2014).

This sighting may not only be linked to oceanographic processes like warming waters by climate-driven changes (Bigelow \& Schroeder, 1953) but also to local productivity events that boost the abundance of zooplankton providing foraging opportunities (Sampson et al., 2010; Jaine et al., 2014) as these have been considered important causes for movement behavior of elasmobranchs (Dewar et al., 2008; Luiz et al., 2009; Sleeman et al., 2010). The concentration of chlorophyll-a has varied spatially and temporally in central Peru; in December 2015 the concentration was high $\left(15 \mathrm{mg} / \mathrm{m}^{3}\right)$, compared to offshore areas $\left(2 \mathrm{mg} / \mathrm{m}^{3}\right)$ and December $2014\left(4 \mathrm{mg} / \mathrm{m}^{3}\right)$ (Imarpe, 2016). In addition, during the sighting we observed a dense mat of $P$. monodon and several dozen siphonophores; these groups have been associated with productive upwelling zones (Gasca \& Suarez, 1991; Gutierrez et al., 2008). Thus, we suggest that $M$. birostris was preying on P. monodon. Even though the observed individual was seen with its cephalic fins closed at $16 \mathrm{~m}$ deep, suggesting a non-feeding behavior (Ari \& Correia, 2008) and recent work has found that $M$. birostris mainly feeds on deep-water zooplankton (Burgess et al., 2016; Stewart et al., 2016), the possibility that this muninid crustacean could be a prey of Mobula spp. shall not be completely discarded as few studies have determined that zooplankton, shrimps, crabs and small fishes are key items on giant manta rays diet (Bigelow \& Schroeder, 1953; Couturier et al., 2012; Rohner et al., 2017).

This sighting is unique because this individual might have migrated $\mathrm{ca} 1000 \mathrm{~km}$ south from eutropical populations. Also, the observed individual was seen alone, with no other members travelling and feeding in schools as it has usually been reported and filmed elsewhere (Couturier et al., 2012). A recent study has shown that $M$. birostris exhibited restricted movements and fine-scale population structure (Stewart et al., 2016). Thus, the origin of this individual and causes for its migration remains unknown. Also, because of the similar morphological characters between $M$. alfredi and $M$. birostris, we recommend to validate the presence of the latter in Peruvian marine ecosystem by using molecular tools.

\section{Conclusions}

This sighting represents the southernmost record of $M$. birostris in the southeastern Pacific $\left(12^{\circ} \mathrm{S}\right)$. Although molecular confirmation is lacking, the observations strongly suggest that the manta ray belonged to $M$. birostris, additionally, this sighting represents the first report of this species in the WTSP-MP and HC-LME. This species is commonly allocated in distribution maps that extend its occurrence to southern Peruvian limits and northern Chile. Yet, this should be revised as this study suggests that the southeastern Pacific distribution of $M$. birostris limits with central Peru. This record is important to hypothesize migration patterns, biological impacts, and contribute with the knowledge of distribution patterns in order to advise decision makers, stakeholders and national fishing authorities.

\section{Abbreviations \\ DW: Disc width; Enfen: Comité Multisectorial encargado del Estudio Nacional del Fenómeno El Niño; ENSO: El Niño Southern Oscillation; HC- LME: Humboldt Current Large Marine Ecosystem; ICEN: El Niño Coastal Index; MP: Marine Province; POI: Peruvian Oscillation Index; SST: Sea Surface Temperature; TEP: Tropical East Pacific; WTSP: Warm Temperate Southeastern Pacific}

\section{Acknowledgements}

We thank Naylamp Diving PADI Dive Center for the diving operation and logistics. We also thank Andrea Marshall for the aid confirming the identity of the specimen, Javier Quiñones for providing information of the thermal anomalies, Cesar O. Pacherres and Phil Jones for reviewing the manuscript.

Funding

No funding was received.

Availability of data and materials

Not applicable.

Authors' contributions

$\mathrm{BM}$ registered the sighting, wrote the paper, prepared figures, and reviewed the drafts of the paper. AGP wrote the paper and reviewed the drafts of the paper. Both authors read and approved the final manuscript.

Ethics approval and consent to participate

Not applicable.

Consent for publication

Not applicable.

Competing interests

The authors declare they have no competing interests.

\section{Publisher's Note}

Springer Nature remains neutral with regard to jurisdictional claims in published maps and institutional affiliations.

\section{Author details}

'Carrera de Biología Marina, Universidad Científica del Sur, Panamericana Sur km 19, 42 Lima, Peru. ${ }^{2}$ Naylamp Diving PADI Dive Center, Av. General Cordova 735, 18 Lima, Peru. ${ }^{3}$ ProDelphinus, Jose Galvez 780, 18 Lima, Peru. ${ }^{4}$ James Cook University, Townsville, QLD 4811, Australia. 
Received: 30 August 2016 Accepted: 2 November 2017 Published online: 09 November 2017

\section{References}

Ari C, Correia JP. Role of sensory cues on food searching behavior of a captive Manta birostris (Chondrichtyes, Mobulidae). Zoo Biol. 2008;27(4):294-304. https://doi.org/10.1002/zoo.20189.

Avila J, Forsberg K, Purizaca W, Harding M, Stewart JD. Distribución y pesquería de la manta raya (Manta birostris) en la costa norte del Perú. In IV Congreso de Ciencias del Mar del Perú. 2014.

Bigelow HB, Schroeder WC. Sawfishes, guitarfishes, skates, and rays. In: Bigelow HB, Schroeder WC, editors. Fishes of the western North Atlantic, part 2. New Haven, CT: Sears Foundation for Marine Research, Yale University; 1953. p. 508-514.

Braun CD, Skomal GB, Thorrold SR, Berumen ML. Movements of the reef manta ray (Manta alfredi) in the Red Sea using satellite and acoustic telemetry. Mar Biol 2015; doi:https://doi.org/10.1007/s00227-015-2760-3.

Burgess KB, Couturier LIE, Marshall AD, Richardson AJ, Weeks S, Bennett MB. Manta birostris, predator of the deep? Insight into the diet of the giant manta ray through stable isotope analysis. R Soc Open Sci. 2016; doi.org/10.1098/rsos.160717.

Bustamante C, Vargas-Caro C, Bennett MB. Not all fish are equal: functional biodiversity of cartilaginous fishes (Elasmobranchii and Holocephali) in Chile. J Fish Biol. 2014;85(5):1617-33.

Chirichigno N, Cornejo RM. Catálogo comentado de los peces marinos del Perú. Instituto del Mar del Perú: Lima; 2001.

Couturier LIE, Marshall AD, Jaine FRA, Kashiwagi T, Pierce SJ, Townsend KA, Weeks SJ, Bennett MB, Richardson AJ. Biology, ecology and conservation of the Mobulidae. J Fish Biol. 2012;80(5):1075-119.

Cowman PF, Bellwood DR. Vicariance across major marine biogeographic barriers: temporal concordance and the relative intensity of hard versus soft barriers. Proc R Soc Lond [Biol]. 2013;280(1768):20131541. https://doi.org/10. 1098/rspb.2013.1541.

Deakos MH, Baker JD, Bejder L. Characteristics of a manta ray Manta alfredi population off Maui, Hawaii, and implications for management. Mar Ecol Prog Ser. 2011;429:245-60

Dewar H, Mous P, Domeier M, Muljadi A, Pet J, Whitty J. Movements and site fidelity of the giant manta ray (Manta birostris), in the komodo Marine Park, Indonesia. Mar Biol. 2008;155(2):121-33.

Duffy CAJ, Abbott D. Sightings of mobulid rays from northern New Zealand, with confirmation of the occurrence of Manta birostris in New Zealand waters. N Z J Mar Freshw Res. 2003;37:715-21.

Dulvy NK, Baum JK, Clarke S, Compagno LV, Cortés E, Domingo A, Fordham S, Fowler S, Francis MP, Gibson C, Martínez J, Musick JA, Soldo A, Stevens JD, Valenti S. You can swim but you can't hide: the global status and conservation of oceanic pelagic sharks and rays. Aquat Conserv. 2008;18:459-82.

Ekman S. Zoogeography of the sea. London: Sidgwick and Jackson Ltd.; 1953.

Enfen (Comité Multisectorial Encargado del Estudio Nacional del Fenómeno El Niño). Informe Técnico Enfen. 2015.

Espino M. El Niño 1997-98: Su efecto sobre el ambiente y los recursos pesqueros en el Perú. Rev Peru Biol. 1999:97-109. http://sisbib.unmsm.edu.pe/ BVRevistas/biologia/vex_1999/pdf/a11.pdf.

Gasca R, Suárez E. Siphonophores of upwelling areas of the Campeche Bank and the Mexican Caribbean Sea. Hydrobiologia. 1991;216(1):497-502.

Gutiérrez M, Ramirez A, Bertrand S, Móron O, Bertrand A. Ecological niches and areas of overlap of the squat lobster Pleuroncodes monodon and Engraulis ringens off Peru. Prog Oceanogr. 2008;79:256-63.

Hinojosa-Alvarez S, Walter RP, Diaz-Jaimes P, Galván-Magaña F, Paig-Tran EM. A potential third manta ray species near the Yucatán peninsula? Evidence for a recently diverged and novel genetic manta group from the Gulf of Mexico. Peer J. 2016;4:e2586. doi.org/10.7717/peerj.2586

Hooker Y. Fauna asociada a las aguas cálidas presentes en la bahía de Pucusana durante El Niño 97-98. Informe Progresivo IMARPE. 1998.

Imarpe (Instituto del Mar del Perú). Informe de las condiciones oceanográficas y biológico-pesqueras. 2016. http://www.imarpe.pe/imarpe/lista.php?id_ seccion=10138290000000000000000. Accessed 17 Aug 2017.

Jaine FRA, Rohner CA, Weeks SJ, Couturier LIE, Bennett MB, Townsend KA, Richardson AJ. Movements and habitat use of reef manta ray off eastern Australia: offshore excursions, deep diving and eddy affinity revealed by satellite telemetry. Mar Ecol Prog Ser. 2014;510:73-86. https://doi.org/10.3354/meps10910.

Kashiwagi T, Marshall AD, Bennett MB, Ovenden JR. Habitat segregation and mosaic sympatry of the two species of manta ray in the Indian and pacific
Oceans: Manta alfredi and M. birostris. Mar Biodivers Rec, 2011; doi:https://doi. org/10.1017/S1755267211000479.

Kashiwagi T, Marshall AD, Bennett MB, Ovenden JR. The genetic signature of recent speciation in manta rays (Manta alfredi and $M$. birostris). Mol Phylogenet Evol. 2012;64:212-8. https://doi.org/10.1016/j.ympev.2012.03.020.

Lawson JM, Fordham SV, O'Malley MP, Davidson LNK, Walls RHL, Heupel MR, Stevens G, Fernando D, Budziak A, Simpfendorfer CA, Ender I, Francis MP, Notarbartolo di Sciara G, Dulvy NK. Sympathy for the devil: a conservation strategy for devil and manta rays. Peer J. 2017;5:e3027. https:/doi.org/10.7717/peerj.3027

Luiz OJ, Balboni AP, Kodja G, Andrade M, Marum H. Seasonal occurrences of Manta birostris (Chondrichthyes: Mobulidae) in southeastern Brazil. Ichthyol Res. 2009;56(1):96-9.

Marshall AD, Bennett MB, Kodja G, Hinojosa-Alvarez S, Galvan-Magana F, Harding M, Stevens G, Kashiwagi T. Manta birostris. The IUCN Red List of Threatened Species 2011: e.T198921A9108067; https://doi.org/10.2305/IUCN.UK.2011-2. RLTS.T198921A9108067.en. Accessed on 05 April 2016.

Marshall AD, Compagno LV, Bennett MB. Redescription of the genus Manta with resurrection of Manta alfredi (Krefft, 1868) (Chondrichthyes; Myliobatoidei; Mobulidae). Zootaxa. 2009;2301:1-28.

Marshall AD, Dudgeon CL, Bennett MB. Size and structure of a photographically identified population of manta rays Manta alfredi in southern Mozambique. Mar Biol. 2011;158:1111-24. https://doi.org/10.1007/s00227-011-1634-6.

Peruvian Dark Angel. https://vimeo.com/150842390. Accessed 20 April 2017.

Poortvliet M, Olsen JL, Croll DA, Bernardi G, Newton K, Kollias S, O'Sullivan J, Fernando D, Stevens G, Galván Magaña F, Seret B, Wintner S, Hoarau G. A dated molecular phylogeny of manta and devil rays (Mobulidae) based on mitogenome and nuclear sequences. Mol Phylogenet Evol. 2015;83:72-85.

Purca S, Antezana T, Riquelme R. Cambios de frecuencia e intensidad El Niño y La Niña asociados a un reciente cambio de régimen frente al Perú Costero. Boletín Técnico del Imarpe. 2000;

Rohner CA, Burgess KB, Rambahiniarison JM, Stewart JD, Ponzo A, Richardson AJ. Mobulid rays feed on euphausiids in the Bohol Sea. R Soc Open Sci. 2017;4:161060.

Rubin RD, Kumli KR, Chilcott G. Dive characteristics and movement patterns of acoustic and satellite-tagged manta rays (Manta birostris) in the Revillagigedos Islands of Mexico. In Joint Meeting of Ichthyologists and Herpetologists. Montreal, Canada. 2008.

Sampson L, Galván-Magaña F, De Silva-Dávila R, Aguíniiga-García S, O'Sullivan JB. Diet and trophic position of the devil rays Mobula thurstoni and Mobula japanica as inferred from stable isotope analysis. J Mar Biol Assoc U K. 2010;90(05):969-76.

Sernanp (Servicio Nacional de Áreas Naturales Protegidas). Establecimiento de la Reserva Nacional Sistema de Islas, Islotes y Puntas Guaneras. 2009. Lima, Perú.

Sielfeld W, Laudien J, Vargas M, Villegas M. El Niño induced changes of the coastal fish fauna off northern Chile and implications for ichthyogeography. Rev Biol Mar Oceanogr. 2010;45(1):705-22.

Sleeman JC, Meekan MG, Fitzpatrick BJ, Steinberg CR, Ancel R, Bradshaw CJA. Oceanographic and atmospheric phenomena influence the abundance of whale sharks at Ningaloo reef, Western Australia. J Exp Marine Biol. 2010;382(2):77-81.

Spalding MD, Fox HE, Allen GR, Davidson N, Ferdaña ZA, Finlayson M, et al. Marine ecoregions of the world: a bioregionalization of coastal and shelf areas. Bioscience. 2007;57(7):573-83. https://doi.org/10.1641/b570707.

Stewart JD, Beale CS, Fernando D, Sianipar AB, Burton RS, Semmens BX, AburtoOropeza O. Spatial ecology and conservation of Manta birostris in the indoPacific. Biocon. 2016;200:178-83. doi.org/10.1016/j.biocon.2016.05.016

Stewart JD, Hoyos-Padilla EM, Kumli KR, Rubin RD. Deep-water feeding and behavioral plasticity in Manta Birostris revealed by archival tags and submersible observations. Zoology. 2016;119(5):406-13.

Takahashi K, Mosquera K, Reupo J. El Índice Costero El Niño (ICEN): historia y actualización. Boletín Técnico del Instituto Geofísico del Perú. 2014;1:8-9.

Visser IN, Fertl D, Pusser LT. Melanistic southern right-whale dolphins (Lissodelphis peronii) off Kaikoura, New Zealand, with records of other anomalously allblack cetaceans. N Z J Mar Freshwater Res. 2004:38:833-6.

Walter RP, Kessel ST, Alhasan N, Fisk AT, Heath DD, Chekchak T, Klaus R, Younis R, Hill G, Jones B, Braun CD, Berumen ML, DiBattista JD, Priest MA, Hussey NE. First record of living Manta alfredi x Manta birostris hybrid. Mar Biodiv. 2014; doi:https://doi.org/10.1007/s12526-013-0183-2.

White WT, Corrigan S, Yang L, Henderson AC, Bazinet AL, Swofford DL, Naylor GJP. Phylogeny of the manta and devil rays (Chondrichthyes: Mobulidae), with an updated taxonomic arrangement for the family. Zool J Linnean Soc. 2017;XX:1-26.

White WT, Giles J, Dharmadi, Potter IC. Data on the bycatch fishery and reproductive biology of mobulid rays (Myliobatiformes) in Indonesia. Fish Res. 2006;82(1-3):65-73. 